\title{
Planning of the sanitary landfill system in Surakarta city
}

\author{
David Anwar, \\ Faculty of Engineering,Narotama University Surabaya \\ davidanwar468@gmail.com \\ RosslanEdySantosa \\ Faculty of Engineering,Narotama University Surabaya
}

\begin{abstract}
ABSTRACK
Waste processing sites have a sueful life, as the activities and populations increase in the Surakarta City has led to increasing volume of the garbage that come to landfill every day. Putri Cempo's Landfill operation system still uses the conventional system, called open dumping. This system causes accumulation of garbage increasingly mountainous and not polluted. Therefore, a system called sanitary landfill is planned to increase landfill capacity and extend the life of landfill.The purpose of this final project is to plan the development of landfill in Surakarta City with a sanitary landfill system. This development is made by making landfill cell in lieu of the open dumping system. The method of landfill cell waste using the trench method to further optimize landfill cell land. The development of TPA using a sanitary landfill was carried out in an area of $6.7 \mathrm{Ha}$. With the prediction of the amount of waste entering the landfill in 2026 around 15.041 tons/year. The age of using landfill is predicted to range from 5 years and the

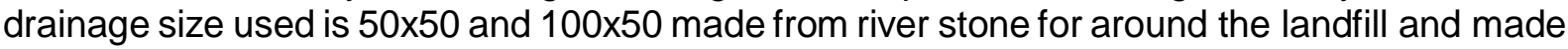
from precast cell for around the facilities building.
\end{abstract}

Keywords :Planning, Gerbage, Sanitary Landfill

\section{INTRODUCTION}

Surakarta City is one of the cities in Central Java Province. Palace, batik, and Klewer markets are three things that become the identity symbol of Surakarta City. In general the city of Surakarta is a lowland and is located between the confluence of the rivers Pepe, Jenes with the Bengawan Solo which has a height of \pm 92 from the sea level. Surakarta City is a medium city with a population of around 510,077 people with an average population growth of $0.08 \%$ per year (BPS, 2014).As population growth continues to increase each year, the volume of waste produced increases. Data from the Surakarta City Environmental Agency (DLH) in 2016 , the municipal waste volume was 109,283 tons / year or the average number per day reached 299,405 kg / day (DLH Surakarta, 2016).

In terms of processing waste, Surakarta City has a landfill as a Final Processing Site. Surakarta City Landfill or called TPA Putri Cempo has an area of $\pm 17 \mathrm{Ha}$ and is located in JebresSubdistrict, which is used for TPA of $\pm 13 \mathrm{Ha}$, the remaining $1 \mathrm{Ha}$ is used for facilities and infrastructure such as offices and parking lots, $2 \mathrm{Ha}$ is used for IPLT (Installation Processing of Sludge and Feces), and 1 Ha was used as Princess Cempo's release. Putri Cempo landfill has been operating since 1986, using an open dumping treatment system.

The open dumping landfill system is currently not well controlled. The disposal system is still careless and the transportation operations are still limited. The garbage entering the landfill is not all recorded and inspected. Landfill operations regarding landfill facilities such as road maintenance, rainwater drainage, and routine operations are still not practiced. 


\section{Study Literature}

Municipal waste management is one of the hot issues that have been talked about a lot by the world community in recent years. Where it also relates to sanitation services and prevention of environmental pollution. If urban waste is not processed properly, it can damage the aesthetics of the city, cause odor and pollute the environment. Integrated solid waste management is a task that includes meeting the obstacles of technical, economic and social aspects. This combines the collection distance and processing method used to handle all material in waste in an effective, environmentally friendly, economical and socially acceptable way (McDougall et al, 2001).

The final stage of waste management is disposal. Where this disposal is carried out at the landfill, the Final Processing Site. According to Law No. 18 of 2008, the Final Processing Site (TPA) is a place where waste reaches the final stage in its management. Landfill is a place where garbage is safely isolated so as not to cause interference with the surrounding environment. TPA based on SNI 03-3241-1994 waste landfill is a physical facility for the ongoing waste disposal activity, hereinafter referred to as the Final Processing Site (TPA). Final waste disposal is a place to get rid of / quarantine municipal waste so it is safe.The final processing of waste at the landfill must pay attention to:

a. The garbage that can enter the landfill is household waste, household waste, and residue;

b. Waste that is prohibited from being filled in landfill includes:

1) 1). liquid waste originating from household activities;

2) 2). waste which is categorized as hazardous and toxic material in accordance with laws and regulations; and

3) 3). medical waste from health services.

c. The residue as referred to in letter a is notcategorized as hazardous and toxic materials or containing hazardous and toxic material waste;

d. In the event that there is a category of hazardous and toxic waste or containing hazardous and toxic material waste in the landfill, it must be stored in a temporary storage area in accordance with the provisions of laws and regulations concerning the management of hazardous and toxic material waste; and

e. Do not carry out animal husbandry activities at TPA.

Landfill planning is carried out as a waste disposal control method. The landfill location must pay attention to the geological, hydrological, and conformity conditions of the environment. A landfill should not have an open dumping system, because it causes odor, smoke, unsightly eyes, insect and rodent problems, and so on. The most important condition of TPA is not producing pollutants and being able to be degraded by the environment (Yaaresya, 2014).

Open dumping is one of the simplest waste handling systems, namely garbage is piled up in certain areas continuously without being covered with overburden. Disposal of the open dumping system is not recommended because it can have a negative impact on the environment which will cause leacheate in the embankment layer and so it will seep the soil under it. Leacheate is very damaging and can cause unpleasant odors (Silvia, 2011).This method is the oldest method known to man in a garbage disposal system. In this method, waste is only disposed of or dumped in a place without land cover, so it can cause disruption to the environment such as the development of diseases, odors, pollution of surface water and ground water, and fire hazards (Ismeidi, 2006).Social resistance to the existence of this type of landfill also continues to flow from various places, residents around the landfill generally do not agree that there is an open dumping landfill near their homes, because the smell and disease of the garbage mountains is very disturbing. Therefore, handling waste that is not good or does not reach health requirements such as open dumping will increase the fly population so that the possibility of diarrheal disease will increase.

Sanitary Landfill is a healthy system of landfill where waste is dumped in low places or trenches are dug to collect garbage, then garbage is piled up with soil carried out layer by layer in such a way that waste is not in the open (Tchobanoglous et al., 1993). Sanitary landfill 
is a means of storing waste into the environment that is prepared and operated systematically, with the spread and compaction of waste in the storage area, as well as the daily closure of waste (Damanhuri et al., 2006).

In the Operation Manual and Maintenance of Landfill and Sanitary Landfill Controlled Landfill Systems by Enri Damanhuri et al., 2006, there are several things that need to be considered for the landfill base layer system, namely:

1. Re-examine the depth of the groundwater level in the rainy season against the base layer of the landfill which is a minimum of 3 meters before the subgrade is peeled and compacted.

2. Solidify the subgrade with the machine, and aim the base slope towards the leachate collection system. Base coatings should:

a. Not crushed while waiting for use, such as exposure to rain and heat

b. Not eroded due to routine operations, especially as a result of the garbage truck and heavy machine operation on it

c. Fine rubbish is not carried into the leachate collection system, and allows leachate to flow and directed downward.

3. When using clay, do compaction of layers of at least 2 layers with a thickness of at least $250 \mathrm{~mm}$, until it reaches a density of $95 \%$. The minimum graduation from the soil mixture has a maximum graduation of $1 \times 10-7 \mathrm{~cm} / \mathrm{sec}$.

4. dMeasure the slope of the TPA base layer with the slope required $1-2 \%$ towards the leachate collection / processing site.Sanitary landfill, which consists of:

a. Protective soil layer as thick as $30 \mathrm{~cm}$ minimum

b. Under the layer there is a barrier layer of geotextile or woven bamboo, which blocks the protective soil with leachate capture media

c. Leachate media with a minimum thickness of $15 \mathrm{~cm}$ leachate catches, together with leachate collection channels in the form of gravel media with a diameter of $30-50 \mathrm{~mm}$, a minimum thickness of $20 \mathrm{~cm}$ that surrounds the $8 \mathrm{~mm}$ perforation pipe of PVC, with a minimum diameter of $150 \mathrm{~mm}$. The distance between the holes (perforations) is $5 \mathrm{~cm}$. On gravel media.

5. $f$ according to the design, geosynthetics such as geomembrane, geotextile, geonet, and so on, the installation of this material should be adjusted according to the technical specifications planned, and carried out by contractors who are experienced in this field.

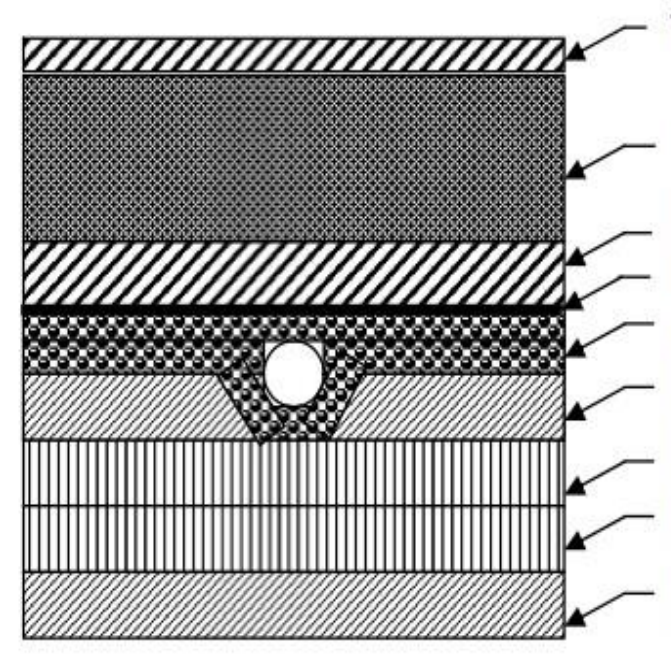

Tanah Biasa, $30 \mathrm{~cm}$

\section{Sampah}

Tanah Biasa, $30 \mathrm{~cm}, \mathrm{k}=10^{-4} \mathrm{~cm} / \operatorname{det}$

Geotekstil

Kerikil, $15 \mathrm{~cm}$

Tanah Asli Dipadatkan, $15 \mathrm{~cm}, \mathrm{k}=10^{-7} \mathrm{~cm} /$ det

Tanah Liat, $25 \mathrm{~cm}$

Tanah Liat, $25 \mathrm{~cm}$

Tanah Asli Dipadatkan, $\mathrm{k}=10^{-5} \mathrm{~cm} / \mathrm{det}$

Figure1. 


\section{METHODOLOGY}

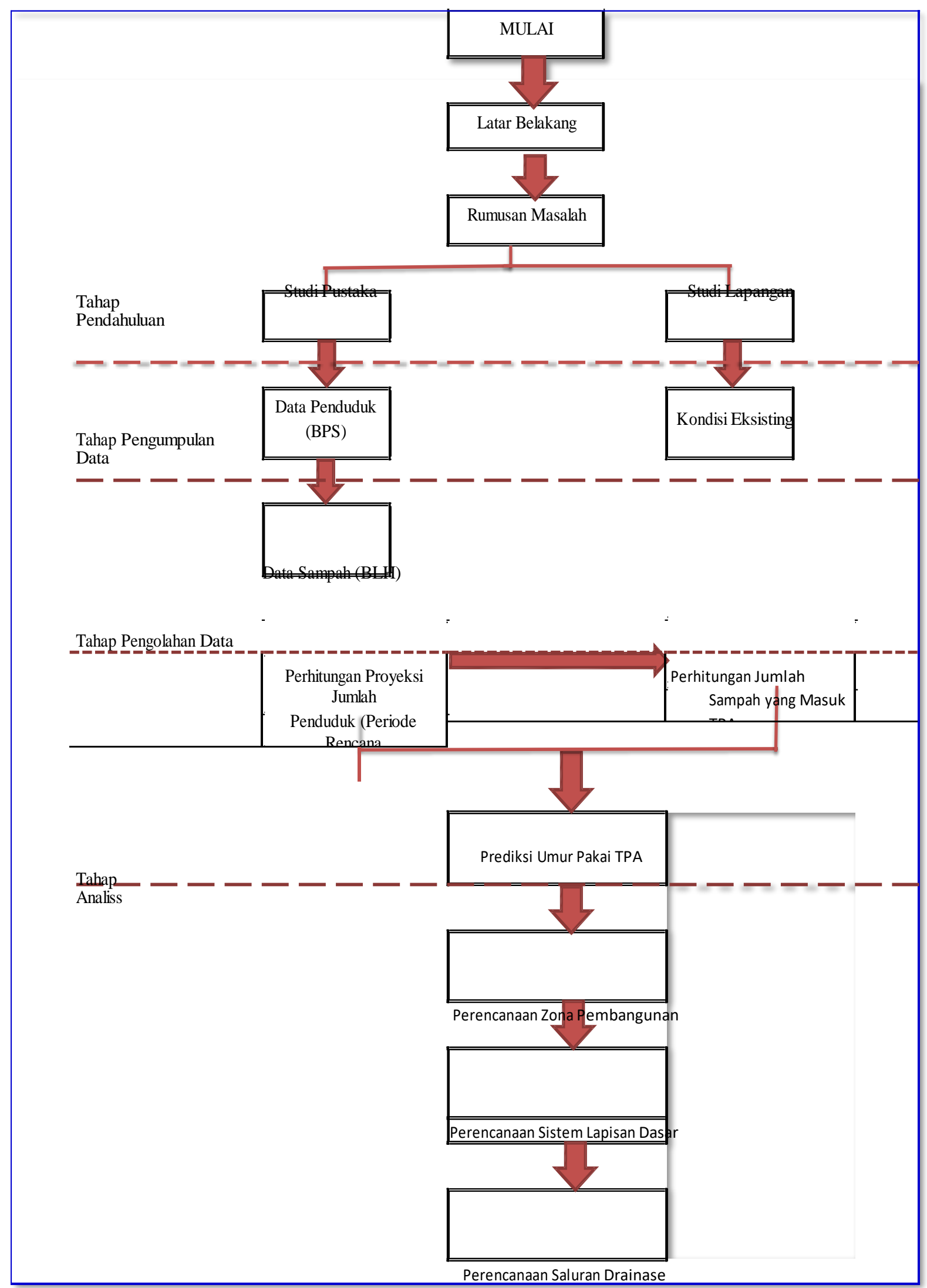

Tahap Kesimpulan 
Figure2.

\section{RESULTS AND DISCUSSION}

Prediction of Population in Surakarta City in 2026 :

Table 4.4 The Prediction of the Population of Surakarta City from 2017 to 2026

\begin{tabular}{|c|c|c|}
\hline NO & YEAR & NUMBER OF POPULATION \\
\hline 1 & 2017 & 516.485 \\
\hline 2 & 2018 & 518.809 \\
\hline 3 & 2019 & 521.144 \\
\hline 4 & 2020 & 523.489 \\
\hline 5 & 2021 & 525.844 \\
\hline 6 & 2022 & 528.211 \\
\hline 7 & 2023 & 530.588 \\
\hline 8 & 2024 & 532.975 \\
\hline 9 & 2025 & 535.374 \\
\hline 10 & 2026 & 537.783 \\
\hline & $L A H$ & 5.270 .701 \\
\hline
\end{tabular}

Prediction of the Number of Waste in Surakarta City in 2026

Table 4.6 Prediction of the Amount of Waste in 2017 Up to 2026

\begin{tabular}{ccc}
\hline NO & YEAR & NUMBER OF TRASH (TON) \\
\hline 1 & 2017 & 110.369 \\
2 & 2018 & 114.617 \\
3 & 2019 & 119.027 \\
4 & 2020 & 123.608 \\
5 & 2021 & 128.365 \\
6 & 2022 & 133.305 \\
7 & 2023 & 138.435 \\
8 & 2024 & 143.763 \\
9 & 2025 & 149.295 \\
10 & 2026 & 155.041 \\
\hline
\end{tabular}

It is planned that each cell lift has a height of $2 \mathrm{~m}$. To achieve the sanitary landfill standard, waste collection is also carried out every day with overburden. The following is the calculation of the landfill zone above:

a. Lift height plan $=1.5 \mathrm{~m}$

b. Operating road area $=3 \mathrm{~m}$

Calculation of cell capacity by calculating the volume of each elevator using the trapped limas formula (equation 4.3). The calculation of zone capacity can be found in the capacity calculation table in the appendix, where the capacity of the zone / cell is $1,090,408,667 \mathrm{~m} 3$

Vlift $=1 / 3 \times h\left(\mathrm{La}+(\mathrm{La} \times \mathrm{Lb})^{1 / 2}+\mathrm{Lb}\right)$

The intermediate land requirement for sanitary landfill cells is planned to be $30 \mathrm{~cm}$ and $10 \mathrm{~cm}$ thick for daily cover land. This is in accordance with the provisions of PerMen. PU No. 3 of 2013. The results of the calculation of cover land requirements can be seen in Table 4.7. 
Table 4.7 Land Covering Needs Between

\begin{tabular}{cccc}
\hline LIFT & $\begin{array}{c}\text { VOLUME LIFT } \\
(\mathrm{M} 3)\end{array}$ & $\begin{array}{c}\text { PERCENTAGE } \\
\text { OF CLOSING } \\
\text { SOIL NEEDS }\end{array}$ & $\begin{array}{c}\text { CLOSING SOIL } \\
\text { NEEDS (M3) }\end{array}$ \\
\hline 1 & 171895,6725 & 0,2 & 34379,135 \\
2 & 171895,6725 & 0,2 & 34379,135 \\
3 & 164155,6099 & 0,2 & 32831,122 \\
4 & 156577,5426 & 0,2 & 31315,509 \\
5 & 149161,4702 & 0,2 & 29832,294 \\
6 & 141907,3919 & 0,2 & 28381,478 \\
7 & 134815,3073 & 0,2 & 26963,061 \\
\hline \multicolumn{5}{c}{ TOTAL } \\
\hline
\end{tabular}

while daily cover land requirements can be seen in Table 4.8 as follows

Table 4.8 Daily Closing Needs

\begin{tabular}{ccccc}
\hline Year & $\begin{array}{c}\text { Volume Of } \\
\text { Waste Powder } \\
\text { Per Day (M3) }\end{array}$ & $\begin{array}{c}\text { Percentage } \\
\text { Of Closing } \\
\text { Soil Needs }\end{array}$ & $\begin{array}{c}\text { Needs Of } \\
\text { Land Daily } \\
\text { Cover Per } \\
\text { Day (M3) }\end{array}$ & $\begin{array}{c}\text { Needs Of Daily } \\
\text { Closing Soil For } \\
\text { Year (M3) }\end{array}$ \\
\hline 2017 & 314,91 & 0,2 & 62,98 & $22.988,28$ \\
2018 & 300,73 & 0,2 & 60,15 & $21.953,17$ \\
2019 & 286,85 & 0,2 & 57,37 & $20.939,73$ \\
2020 & 273,26 & 0,2 & 54,65 & $19.947,95$ \\
2021 & 259,97 & 0,2 & 51,99 & $18.977,83$ \\
2022 & 246,98 & 0,2 & 49,40 & $18.029,38$ \\
2023 & 234,28 & 0,2 & 46,86 & $17.102,59$ \\
2024 & 221,88 & 0,2 & 44,38 & $16.197,47$ \\
2025 & 209,78 & 0,2 & 41,96 & $15.314,01$ \\
2026 & 197,98 & 0,2 & 39,60 & $14.452,21$ \\
\hline
\end{tabular}

It is necessary to know the carrying capacity of the soil to find out whether the land in the landfill can accommodate the load from the landfill, the calculation is as follows:

$$
\begin{gathered}
\text { Soil bearing capacity }=\frac{\text { ju mlah lif } \mathrm{t} \times \text { tinggi li } \mathrm{ft} \times \text { densitas s ampah }}{1000} \\
=\frac{7 \times 1,5 \times 600}{1000}=6,3 \mathrm{ton} / \mathrm{m}^{2}
\end{gathered}
$$

The carrying capacity of this land should be compared to the soil carrying capacity data based on the results of the sondir and boring tests on the site. Because of the limitations of the data, the planner compared the height of the existing cell, and it was decided that the carrying capacity of the soil was still sufficient because the height of the development landfill zone was the same as the existing zone height of $10.5 \mathrm{~m}$ (7 lifts).

The maximum daily rainfall calculation uses the Gumble method. In this method, the average rainfall data used from 2012 to 2016 , namely the value of $\mathrm{Ri}$ is the average rainfall every year, while $R$ is the overall average of $918,133 \mathrm{~mm} /$ year.

The choice of method to be used is based on the calculation of rainfall intensity which has a different rain intensity coverage or rain intensity range above other methods. So what is 
taken is a method that has a large rainfall intensity value. HHM data used is taken from the Gumble method HHM data contained in previous calculations. Based on calculations, the method with the greatest intensity is the Van Breen method.

In the calculation of the selection of the rain intensity formula used 3 methods, namely:

a. Talbot Method

b. Sherman's method

c. Ishiguro's method

Of the three methods, which will be widely used is the method that has the smallest curve of intensity. Whereas the PUH used is PUH 2, 5, 10 because these PUHs are respectively considered suitable for tertiary, secondary, primary channel planning. Calculations are carried out with a duration of $5,10,20,40,60,120,240$ minutes.

Based on calculations, the method that has the smallest intensity curve is found in the Talbot method.

$$
\begin{aligned}
& \mathrm{I}=\frac{\mathrm{a}}{\mathrm{t}+\mathrm{b}} \\
& \mathrm{a}=\frac{\left(\sum I . t\right)\left(\sum I\right)^{2}\left(\sum I \cdot t\right)\left(\sum I\right)}{\left.\left(\sum \Sigma\right)^{2}\right)-\left(\sum\right)^{2}} \\
& \mathrm{~b}=\frac{(\Sigma \mathrm{I})\left(\sum \mathrm{I} . \mathrm{t}\right)-\mathrm{N}\left(\Sigma \mathrm{I}^{2} . \mathrm{t}\right)}{\left.N(\Sigma)^{2}\right)-(\Sigma)}
\end{aligned}
$$

Drainage in the landfill is needed to hold rainwater and distribute it to water bodies. According to PerMen PU No. 3 of 2013, drainage is divided into two, namely permanent and temporary drainage. Permanent drainage is drainage that is located around offices, weigh bridges, landfill hangars and other utility areas that are not landfill cells. While temporary drainage is drainage around the landfill cell.

After getting runoff discharge, the next step is to determine the dimensions of the channel. The channel used is a rectangular channel with channel planning based on optimum hydraulic cross section so that the cross-sectional area can have a maximum capacity.

The life span or age of the landfill development can be calculated by comparing the volume of waste to be dumped in the landfill with the available cell capacity.

The results of the lifetime calculations are then carried out roundup formulas on Microsoft Excel. The allowable value limit is 1 for roundup results. If more than that, the landfill zone exceeds its useful life. The lifetime of the landfill is 5 years (2017-2021).

\begin{tabular}{cccccc}
\hline YEAR & $\begin{array}{c}\text { Total Deposits } \\
\text { Accumulated(m3/year) }\end{array}$ & $\begin{array}{c}\text { Zone Volume } \\
\text { Accumulation } \mathrm{m} 3\end{array}$ & Zone TPA & $\begin{array}{c}\text { Landfill Zone } \\
\text { (After } \\
\text { Roundup) }\end{array}$ \\
\cline { 1 - 1 } 2017 & 220738.1027 & 1323829.205 & & 0.166742131 & 1 \\
2019 & 449971.1119 & 1323829.205 & & 0.339901182 & 1 \\
2020 & 688025.9464 & 1323829.205 & & 0.519724103 & 1 \\
2021 & 935242.1063 & 1323829.205 & & 0.706467347 & 1 \\
2022 & 1191972.157 & 1323829.205 & & 0.900397236 & 1 \\
2023 & 1458582.231 & 1323829.205 & & 1.101790341 & 2 \\
2024 & 1735452.554 & 1323829.205 & & 1.310933878 & 2 \\
2025 & 2022977.981 & 1323829.205 & & 1.528126116 & 2 \\
2026 & 2321568.564 & 1323829.205 & 1.7536768 & 2 \\
& 2631650.137 & 1323829.205 & 1.987907599 & 2
\end{tabular}

\section{CONCLUTION}

Based on the results of the planning that has been done in the preparation of this Final Project conclusions can be drawn, as follows:

1. From the data obtained in the Surakarta city BPS, the amount of waste volume and population in 2011 - 2016 can be calculated for the projected garbage up to the desired year. For this Final Project, the projections / predictions of the amount of waste entering Putri Cempo landfill in 2026 will be 15,041 tons / year. 
2. Planning for the development of the Putri Cempo landfill using a sanitary landfill system is carried out on an area of around 6.7 ha near the old landfill and adjacent to the river. Landfill excavation is planned to be 1.5 meters deep. Daily land requirements for landfill cell deposits are around $62.98 \mathrm{~m} 3$ per day and around 22,988 $\mathrm{m} 3$ per year. To complete the landfill cell planning, a drainage plan is also planned for the Putri Cempo landfill. From the rainfall data in 2012-2016 obtained from BPS, it can be predicted that the annual planned rainfall will result in the flow of water that will pass through the drainage channel. From the planning, there are two types of drainage channels, namely $100 \times 50$ and $50 \times 50$. Drainage channels around landfill cells are planned with river stones because they are considered stronger and can withstand pressure from landfill cell soil, while channels for surrounding landfill facilities use precast because it is practical.

3. With the projection / prediction of the amount of waste entering the Putri Cempo landfill, and after planning for the sanitary landfill, the life expectancy of the landfill can be known. Based on the useful life of Putri Cempo landfill after being developed with a 5-year-old sanitary landfill.

\section{REFERENCES}

BadanPusatStatistik Kota Surakarta. 2014. Luas Wilayah, JumlahPenduduk, RasioJenisKelamindan Tingkat KepadatanTiapKecamatan. Surakarta.

BadanStandarisasi Nasional Tata Cara TeknikOperasionalPengelolaanSampahPerkotaan (SNI 19-2454-2002). Jakarta.

BadanStandarisasi Nasional PengelolaanSampah Di Pemukiman (SNI 3242 : 2008). Jakarta.

$\begin{array}{llll}\text { Damanhuri, E., Ismaria, } & \text { R. }\end{array}$ PedomanPengoperasiandanPemeliharaanTempatPembuanganAkhir (TPA) Sistem Controlled Landfill dan Sanitary JurusanTeknikLingkunganFakultasTeknikSipildanPerencanaan, Landfill. Bandung. Bandung.

DinasLingkunganHidup Kota Surakarta. 2016. ProfilPengolaanPersampahan Kota Surakarta. Surakarta.

DitjenCiptaKarya. 2016. Kota Surakarta.Surakarta.

El-Fadel, M., Findikakis, A.N., danLeckie, J.O. 1997. "Enviromental Impacts Of Solid Waste Landfill'. Journal of Enviromental Management, Vol. 50, No, 1, pp. 1-25.

Gelbert, M., et. Al., 1996. "KonsepPendidikanLingkunganHidupdan Wall Chart". BukuPanduanPendidikanLingkunganHidup, PPPGT/VEDC. Malang.

Ismeidi., EndahAngreini. danHermin S.T. 2015. "EvaluasiSistemPembuanganAkhirSampah Di TPA Ngadirojo Kota Wonogiri". BidangKeahlianTeknikPrasaranaLingkunganPermukimanInstitutTeknologiSepuluhNope mber. Surabaya.

Kristi, Yaaresya William. 2014. "PerencanaanPengembangan TPA Kota Surakarta DenganSistem Sanitary Landfill". TugasAkhirlnstitutTeknologiSepuluhNopember. Surabaya.

Luayik, NurFathin. 2015. "EvaluasiDampak TPA Metode Open Dumping Di KabupatenBangkalan. TugasAkhirFakultasllmuAdministrasiUniversitas Madura. Bangkalan.

PeraturanMenteriPekerjaanUmum No. $3 \quad$ Tahun 2013. PenyelenggaraanPrasaranadanSaranaPersampahandalamPenangananSampahRumah TanggadanSampahSejenisSampahRumahTangga. Jakarta.

Pramono, Rizal Drajat. 2011. "EstimasiDayaTampungTempatPembuanganAkhir (TPA) Putri Cempo Di Kotamadya Surakarta PadaTahun 2015". TugasAkhirFakultasTeknikUniversitasSebelasMaret Surakarta. Surakarta.

Ratih, Silvia Yulita. 2011. "EvaluasiMetodePengelolaanSampahUntukUmurLayanan Di TPA Putri Cempo". TeknikSipilUniversitas Surakarta. Surakarta.

Riadi, Muchlisin. 2015. "Pengertian, JenisdanDampakSampah". 
Santosa, F.R.E.,Hermana, J. 2012. “Mapping of Environmental Health Risk Area for Surabaya City as An Evaluation of Millenium Development Goals 2015". International Journal of Academic Research. Vol. 4. No. 1. Surabaya.

Santosa, F.R.E. 2016. "ProfilSanitasi Wilayah untukPenentuanSistem Air LimbahDomestik (StudiKasus: Kota Surabaya)".

Disertasi.

Program PascasarjanaJurusanTeknikLingkungan. FakultasTeknikSipildanPerencanaan. InstitutTeknologiSepuluhNopember. Surabaya.

Sukrorini, Tri., Sri Budiastuti., Ari Handono. Dan Frans P.A. 2014. "KajianDampakTimbunanSampahTerhadapLingkungan Di TempatPembuanganAkhir (TPA) Putri Cempo Surakarta. Magister IImuLingkunganUniversitasSebelasMaret Surakarta. Surakarta.

Tchobanoglous G., Theisen H. dan Vigil S.A. 1993. Integrated Solid Waste Management Engineering Principles adnManagemnt Issues. New York : McGraw-Hill.

Undang - UndangRepublik Indonesia No. 18 Tahun 2008. 2008. PengelolaanSampah. Jakarta. 